\title{
Coenopopulation Structures of Various Plant Species in Yakutia
}

\author{
Varvara Semenova* \\ Institute for Biological Problems of Cryolithozone SB RAS, 677980 Yakutsk, Russia
}

\begin{abstract}
This research work details analysis of the coenopopulation structure of 13 plants of various species in Yakutia and compares them with the characteristic spectra types of their species. The structure of plant coenopopulations was investigated from 2003 to 2019 in Central Yakutia. The left-sided and centered ontogenetic spectra are found in perennial plants with simple ontogenesis and shallow rejuvenation which were studied. The left-sided spectrum is the basic structure of these coenopopulations. The centered ontogenetic spectrum is largely found in unfavorable growing conditions under the impact of grazing and trampling by cattle and horses. This rule applies to the CP structure of Veronica incana which is an evergreen chamaephyte and for which the seasonal anthropogenic load contributes to the mechanical vegetative reproduction of its species, resulting in stable left-sided CP spectra. The ontogenetic spectra of the studied plants coincide with the characteristic spectra of the species and are considered stable.
\end{abstract}

The ontogenetic spectra of plants are applicable to all related life-forms. The value of this demographic indicator for population monitoring is specified by the fact that it may be used to assess the current state of coenopopulations (CP) and forecast their further development. The basic features of ontogenetic spectra (i.e. position and ratio of ups and downs) are directly related to the biological properties of the various species. L. B. Zaugolnova [1] called these population characteristics the characteristic of the ontogenetic spectrum. An actual ontogenetic spectrum corresponding to the characteristic ontogenetic spectrum may serve as an indicator of stable CP state.

For the first time we determined the $\mathrm{CP}$ ontogenetic spectra of plants of various lifeforms on the territory of Yakutia as compared with the types of characteristic ontogenetic spectra of said plants.

The purpose of this research work is the study of the coenopopulation structures of plants of various life-forms in Yakutia.

Our research was carried out from 2003 to 2019 in Central Yakutia. The subject of the study were the coenopopulations of 13 plants of various life-forms: Alyssum lenense Adams., Astragalus lenensis Shemetova Schaulo et Lomon., Clausia aprica (Steph.) Korn.Tr., Gagea pauciflora Turcz. ex Ledeb., Linum komarovii Juz., Oxytropis candicans (Pall.) DC., Papaver jacuticum Peshkova, Patrinia sibirica (L.) Juss., Phlojodicarpus sibiricus

* Corresponding author: vvsemenova-8@yandex.ru 
were (Fisch. Ex Spreng.) K.-Pol., Plantago canescens Adams., Polygonum aviculare L., Valeriana alternifolia Ledeb. and Veronica incana L. In total the CP structure of about 80 plants was studied [2-14].

The vast territory of Yakutia is covered with permafrost the thickness of which reaches 250 to $300 \mathrm{~m}$ in Central Yakutia. The climate of Central Yakutia is characterized by its extremely sharp continentality. The absolute minimum and maximum temperatures covered a range of $102{ }^{\circ} \mathrm{C}$, from $-64{ }^{\circ} \mathrm{C}$ in January up to $+38{ }^{\circ} \mathrm{C}$ in July. With regard to the amount of precipitation, 140 to $180 \mathrm{~mm}$, were registered with the regional level being close to that of the steppes and semi-desert regions of Central Asia [15]. Generally accepted population classification and research techniques were applied in our research work $[16,17]$. L. B. Zaugolnova [1] compared the CP structure of the plants with the types of characteristic spectra of said plants.

The ontogenetic structure of the studied coenopopulations of species depends on the biological properties of plants and the dynamic CP states. The biological characteristics of the studied plants and their CP structure are presented in Table 1 and Table 2. According to L.B. Zaugolnova's [1] classification of plant life-forms making up a significant portion of the population features of the characteristic ontogenetic spectrum, the studied plants belong to taproot possessing plants reproducing by seed with no vegetative reproduction and having a simple type of ontogenesis. The rest of the studied species have a complex type of ontogenesis and vegetative reproduction with shallow and deep rejuvenation. The biomorph type of the studied plants is monocentric, except for Clausia aprica and Veronica incana which possess a long-rooted life-form, in which implicit polycentric biomorphs were observed and documented.

The demographic structure of CP in the studied plants is dependent on both the characteristics of plant biology and on various growing conditions. Left-sided and centered ontogenetic spectra were found during research. Moreover left-sided ontogenetic spectra were noted in all of the CP species under study. Centered CP were found in plants with a tap root system, except for one-year-old Polygonum aviculare as well as Papaver jacuticum, Patrinia sibirica and Phlojodicarpus sibiricus. However the CP of perennial plants was found within plants existing in relatively favorable growing conditions. A centered structure was also found in one CP of Valeriana alternifolia with a short-rootstock and brush-like life-form. The study covered $7 \mathrm{CPs}$ over a 3 year period and centered $\mathrm{CP}$ was recorded only once. For the $\mathrm{CP}$ of plants under study, the increase in the proportion of middle-aged species occurred mainly against the back drop of unfavorable growing conditions caused by anthropogenic impact (the trampling and grazing of cattle and horses), when the percentage of advanced growth decreases with relation to the shared general spectrum.

Table 1. The biological characteristics of the studied plants and the ontogenetic structure of their related $\mathrm{CP}$

\begin{tabular}{|c|l|l|c|c|c|}
\hline No. & Species & Life-form & $\begin{array}{c}\text { Lifetime, } \\
\text { years/ontogenesis }\end{array}$ & $\begin{array}{c}\text { Ontogenetic } \\
\text { spectrum of CP }\end{array}$ & $\begin{array}{c}\text { Characteristic } \\
\text { ontogenetic } \\
\text { spectrum of the } \\
\text { species CP }\end{array}$ \\
\hline 1 & Alyssum lenense & Taproot half-shrub & $\begin{array}{c}7-11 / \\
\text { Simple }\end{array}$ & $\begin{array}{c}\text { Left-sided, } \\
\text { centered }\end{array}$ & Left-sided, centered \\
\hline 2 & $\begin{array}{l}\text { Astragalus } \\
\text { lenensis }\end{array}$ & Taproot chamephyte & $\begin{array}{c}10-24 / \\
\text { Simple }\end{array}$ & $\begin{array}{c}\text { Left-sided, } \\
\text { centered }\end{array}$ & Left-sided, centered \\
\hline 3 & Clausia aprica & $\begin{array}{c}\text { Long-rootstock } \\
\text { taproot herbaceous } \\
\text { perennial plant }\end{array}$ & $\begin{array}{c}1-4 / \\
\text { Complex with } \\
\text { deep rejuvenation }\end{array}$ & Left-sided & Left-sided \\
\hline 4 & Gagea & Bulbous herbaceous & $6-7 /$ & Left-sided & Left-sided \\
\hline
\end{tabular}




\begin{tabular}{|c|c|c|c|c|c|}
\hline & pauciflora & perennial plant & $\begin{array}{c}\text { Complex with } \\
\text { deep rejuvenation }\end{array}$ & & \\
\hline 5 & $\begin{array}{l}\text { Linum } \\
\text { komarovii }\end{array}$ & Taproot chamephyte & $\begin{array}{c}5-7 / \\
\text { Simple }\end{array}$ & $\begin{array}{c}\text { Left-sided, } \\
\text { centered }\end{array}$ & Left-sided, centered \\
\hline 6 & $\begin{array}{l}\text { Oxytropis } \\
\text { candicans }\end{array}$ & $\begin{array}{c}\text { Taproot herbaceous } \\
\text { perennial plant }\end{array}$ & $\begin{array}{l}7-16 / \\
\text { Simple }\end{array}$ & $\begin{array}{c}\text { Left-sided, } \\
\text { centered }\end{array}$ & Left-sided, centered \\
\hline 7 & $\begin{array}{l}\text { Papaver } \\
\text { jacuticum }\end{array}$ & $\begin{array}{c}\text { Taproot herbaceous } \\
\text { perennial plant }\end{array}$ & $\begin{array}{l}4-12 / \\
\text { Simple }\end{array}$ & Left-sided & Left-sided, centered \\
\hline 8 & Patrinia sibirica & $\begin{array}{c}\text { Taproot herbaceous } \\
\text { perennial plant }\end{array}$ & $\begin{array}{l}10-12 / \\
\text { Simple }\end{array}$ & Left-sided & Left-sided, centered \\
\hline 9 & $\begin{array}{l}\text { Phlojodicarpus } \\
\text { sibiricus }\end{array}$ & $\begin{array}{c}\text { Taproot herbaceous } \\
\text { perennial plant }\end{array}$ & $\begin{array}{c}\text { / } \\
\text { Simple }\end{array}$ & Left-sided & Left-sided, centered \\
\hline 10 & $\begin{array}{l}\text { Plantago } \\
\text { canescens }\end{array}$ & $\begin{array}{l}\text { Short-rootstock } \\
\text { taproot herbaceous } \\
\text { perennial plant }\end{array}$ & $\begin{array}{c}4-11 / \\
\text { Complex with } \\
\text { shallow } \\
\text { rejuvenation } \\
\end{array}$ & $\begin{array}{l}\text { Left-sided, } \\
\text { centered }\end{array}$ & Left-sided, centered \\
\hline 11 & $\begin{array}{l}\text { Polygonum } \\
\text { aviculare }\end{array}$ & $\begin{array}{c}\text { Taproot one-year-old } \\
\text { plant }\end{array}$ & $\begin{array}{c}\text { one-year-old / } \\
\text { Simple }\end{array}$ & Left-sided & Left-sided \\
\hline 12 & $\begin{array}{l}\text { Valeriana } \\
\text { alternifolia }\end{array}$ & $\begin{array}{l}\text { Short-rootstock } \\
\text { brush-like plant }\end{array}$ & $\begin{array}{c}10-20 / \\
\text { Complex with } \\
\text { shallow } \\
\text { rejuvenation } \\
\end{array}$ & $\begin{array}{l}\text { Left-sided, } \\
\text { centered }\end{array}$ & Left-sided, centered \\
\hline 13 & Veronica incana & $\begin{array}{c}\text { Loosely-bunched } \\
\text { chamephyte, forms a } \\
\text { short-rootstock } \\
\text { (nature), long- } \\
\text { rootstock (nature), } \\
\text { taproot (culture) } \\
\text { biomorph }\end{array}$ & $\begin{array}{c}13-15 / \\
\text { Complex with } \\
\text { shallow } \\
\text { rejuvenation }\end{array}$ & Left-sided & Left-sided, centered \\
\hline
\end{tabular}

L.B. Zaugolnova's [1] characteristic ontogenetic spectrum for various life-forms basically matches our research. Our research may thus confirm and supplement the occurrence of characteristic plant spectra. The left-sided CP spectrum was found within favorable growing conditions of typical taproot possessing plants with simple ontogenesis provided for no vegetative reproduction. The centered ontogenetic spectra of these plants were found within unfavorable growing conditions under the impact of intensive trampling and grazing by cattle and horses.

The CP structures of plants (Plantago canescens, Valeriana alternifolia, Veronica incana) possessing a complex ontogenesis and shallow system rejuvenation with various life-forms complement the characteristic optional variants encountered in species spectra. The left-sided spectra were found in three studied plants. The centered spectra were reported in CP of Plantago canescens with short-rootstock taproot possessing life-forms and the $\mathrm{CP}$ of Valeriana alternifolia with a short-rootstock brush-like life-form when trampled by humans and grazed of cattle. L.B. Zaugolnova [1] noted that species with a complex ontogenesis and shallow rejuvenation developing according to a monocentric typing, were found only among forest grasses. It should be noted that in addition, there is an exception to the rule stating that the centered CPs are formed under unfavorable conditions for plant growth. Thus, the CP structure of Veronica incana with short-rootstock and longrootstock life-forms possessing shallow rejuvenation within unfavorable growing conditions against the back drop of intensive trampling by people and transport loads, retains the left-sided spectrum. Veronica incana is an evergreen chamaephyte for which seasonal anthropogenic loads contribute to mechanical vegetative reproduction, leading to an increase in the proportion of immature and virginal groups of species within the $\mathrm{CP}$ structure. 
The Clausia aprica and Gagea pauciflora species which possess complex ontogenesis and deep rejuvenation were described within conditions lacking anthropogenic impact. The left-sided spectra were found within these CPs while matching the characteristic spectra of the species.

Table 2. The ontogenetic spectra options for the $\mathrm{CP}$ of the studied species

\begin{tabular}{|c|c|c|c|c|c|c|c|c|c|c|}
\hline No. & Species & $\begin{array}{c}\text { Ontogenetic } \\
\text { spectrum }\end{array}$ & $\mathrm{j}$ & im & $\mathrm{v}$ & $\mathrm{g} 1$ & g2 & g3 & ss & $\mathrm{s}$ \\
\hline & \multirow{2}{*}{ Alyssum lenense } & Left-sided & 20,3 & - & 30,4 & 23,2 & 26,1 & - & - & - \\
\hline & & Centered & 32,7 & - & 15,5 & 9,4 & 41,6 & 0,8 & - & - \\
\hline \multirow{2}{*}{2} & \multirow{2}{*}{ Astragalus lenensis } & Left-sided & 3,1 & 18,8 & 25,0 & 18,8 & 18,8 & 6,2 & 3,1 & 6,2 \\
\hline & & Centered & 2,5 & 8,8 & 18,7 & 21,2 & 26,9 & 16,9 & 5,0 & - \\
\hline 3 & Clausia aprica & Left-sided & 1,1 & 11,9 & 42,0 & 17,0 & 14,5 & 6,1 & 7,4 & - \\
\hline 4 & Gagea pauciflora & Left-sided & 8,4 & 24,3 & 26,9 & 22,5 & 17,9 & - & - & - \\
\hline \multirow{2}{*}{5} & \multirow{2}{*}{ Linum komarovii } & Left-sided & 10,4 & 11,7 & 35,0 & 23,4 & 16,9 & 2,6 & - & - \\
\hline & & Centered & 1,8 & 10,0 & 20,0 & 19,4 & 24,7 & 15,3 & 8,8 & - \\
\hline \multirow{2}{*}{6} & \multirow{2}{*}{ Oxytropis candicans } & Left-sided & 3,3 & 5,6 & 62,2 & 6,7 & 15,6 & 2,2 & 3,3 & 1,1 \\
\hline & & Centered & - & 3,3 & 14,5 & 33,3 & 38,9 & 6,7 & 2,2 & 1,1 \\
\hline 7 & Papaver jacuticum & Left-sided & 3,6 & 41,1 & 10,7 & 19,6 & 19,6 & 5,4 & - & - \\
\hline 8 & Patrinia sibirica & Left-sided & 8,1 & 11,0 & 25,1 & 10,5 & 8,8 & 13,6 & 13,4 & 9,5 \\
\hline 9 & \begin{tabular}{|l|}
$\begin{array}{l}\text { Phlojodicarpus } \\
\text { sibiricus }\end{array}$ \\
\end{tabular} & Left-sided & 42,1 & 7,9 & 35,0 & 3,6 & 5,7 & 1,4 & 4,3 & - \\
\hline 10 & Plantago canescens & Left-sided & 7,55 & 14,84 & 34,85 & 12,24 & 26,23 & 3,19 & 1,1 & - \\
\hline 11 & Polygonum aviculare & Left-sided & - & - & 47,6 & 52,4 & - & - & - & - \\
\hline \multirow{2}{*}{12} & \multirow{2}{*}{ Valeriana alternifolia } & Centered & 18,5 & 8,5 & 20,1 & 13,8 & 28,0 & 5,3 & 5,8 & - \\
\hline & & Left-sided & 69,4 & 19,2 & 4,3 & 4,6 & 2,2 & 0,3 & - & - \\
\hline 13 & Veronica incana & Left-sided & 1,4 & 5,4 & 43,1 & 14,4 & 12,4 & 8,0 & 11,6 & 3,7 \\
\hline
\end{tabular}

Thus, the left-sided and centered ontogenetic spectra are found in the studied perennial plants with simple ontogenesis and shallow rejuvenation. The left-sided spectrum is the basic structure of these coenopopulations. The centered ontogenetic spectrum is found in unfavorable growing conditions under the impact of grazing and trampling by cattle and horses. Within this rule the Veronica incana CP structure has developed, as it is an evergreen chamaephyte seasonal anthropogenic load contributes to the mechanical vegetative reproduction of its species, resulting in stable left-sided $\mathrm{CP}$ spectra.

The ontogenetic spectra of the studied plants matches the characteristic spectra of the associated species and are considered stable. The CP structure depends mainly on the biological properties of plants, the ontogenesis type and the vegetative reproduction nature, as well as on the related morphological structures and responses to anthropogenic factors. 
The research work has carried out within the framework of a state assignment from the Institute for Biological Problems of Cryolithozone SB RAS for 2021 to 2025 on the topic "Vegetation Cover of the Cryolithozone in Taiga Yakutia: Biodiversity, EnvironmentForming Functions, Protection and Rational Use" (state registration No.AAAA21121012190038-0).

\section{References}

1. L. B. Zaugolnova, Population structure of seed plants and problems of their monitoring (St. Petersburg, 1994)

2. V. V. Semenova, N. S. Danilova, Plant resources, 4 (2016)

3. V. V. Semenova, N. S. Danilova, USAA Bulletin, 2 (38) (2017)

4. O. A. Nikolaeva, V. V. Semenova, N.S. Danilova, Bot. magazine. 106, 1 (2021)

5. V. V. Semenova, N. S. Danilova, Plant resources, 3 (2014)

6. V. V. Semenova, N. S. Danilova, Plant resources, 53(4) (2017)

7. V. V. Semenova, O. A. Nikolaeva, Science and Education, 2 (82) (2016)

8. V. V. Semenova, O. A. Nikolaeva, Samara SC RAS Bulletin, 20, 5(2) (2018)

9. V. V. Semenova, NESC FED RAS Bulletin, 4 (2016)

10. V.V.Semenova, Structure of Phlojodicarpus sibiricus cenopopulations (Fisch. Ex Spreng.) K.-Pol. in southern Yakutia, Proceedings of the IX International Conference on Ecological Plant Morphology, dedicated to the memory of I.G. and T. Serebryakov (to the 100th anniversary of the birth of I.G. Serebryakov), December 10-13, Moscow, Volume 2 (2014)

11. V. V. Semenova, N. S. Danilova, Plant resources, 55, 1 (2019)

12. V. V. Semenova, P.S. Egorova: Polyvariety of ontogenesis of Valeriana alternifolia Ledeb. and the structure of its natural coenopopulations in Yakutia (Novosibirsk, Nauka, 2013)

13. N. S. Danilova, V. V. Semenova, Plant resources, 51, 4 (2015)

14. V. V. Semenova, N. S. Danilova, Plant resources, 52, 1 (2016)

15. M. K. Gavrilova, The climate of Central Yakutia (Yakutsk, Book Publishing House 1973)

16. Coenopopulations of plants (Basic concepts and structure) (Moscow, Nauka, 1976)

17. A. A. Uranov, Biological Sciences 2 (1975) 